\title{
ECONOMIC ASPECTS OF VALUE ADDED AGRICULTURE IN UZBEKISTAN
}

Elena HORSKA, Department of Marketing and Trade, Faculty of Economics and Management, Slovak University of Agriculture in Nitra, Tr. A. Hlinku 2, 94976 Nitra, Slovakia, elena.horska@uniag.sk

Alim PULATOV, EcoGIS Centre, Tashkent Institute of Irrigation and Agricultural Mechanization Engineers, Qori Niyoziy 39, 100000 Tashkent, Uzbekistan

Khabibullo PIRMATOV, Department of Marketing and Trade, Faculty of Economics and Management, Slovak University of Agriculture in Nitra, Address: Tr. A. Hlinku 2, 94976 Nitra, Slovakia, hpirmatov@ mail.ru (correspondin author)

The goal of this paper is to analyse socio-economic role of value added agriculture in Uzbekistan. The main agricultural exports are cotton (raw and yarn), fruits, vegetables, leather, wool and fur. There is an opportunity to acquire more social and economic advantages by exporting finished goods, which are made out of primary agricultural commodities. Adding value to agricultural products lead to increasing the share of finished goods in export, supplying import-substituting products, improving infrastructure in rural areas, providing new jobs and growing people's income. The paper presents the analyse of the agriculture sector in GDP and the production dynamics of the primary agricultural commodities during 2005-2014, as well as comparison the share of cotton, fruits, vegetables and leather in export in 2005 and 2014. Based on the analyses it is recommended to widely use value added agriculture in order to support people, who are living in rural areas in Uzbekistan.

Keywords: export, primary agricultural commodities, share, economic role, value added agriculture

\section{INTRODUCTION}

Agriculture plays an important role in the livelihoods of rural communities in Uzbekistan. Horticultural products, fruits and vegetables are the main source of income for smallholder farmers, many of whom operate on small plots of land (about 0.2 hectares) known as dehkan. The horticulture subsector is expected to grow, given Uzbekistan's favourable climate and demand from neighbouring countries. Livestock is another income generator for rural families, accounting for about 45 per cent of gross agricultural output. The subsector contributes substantially to national food security and acts as an economic and nutritional safety net for rural households. Most of its production comes from the 4.7 million small dehkan farms. (IFAD, 2015).

Moreover, country's population is growing year by year. Uzbekistan with 31,5 million people (50,6\% - urban and 49,4\% - rural residents) is considered as the most populated country in the Central Asia. (SCRUS, 2016).

Value added agriculture (VAA) creates more advantage for both rural and country development as a whole. It increases the share of finished goods in the country's export and supplying import-substituting products. Adding value to agricultural products leads to providing new jobs, improving the infrastructure and growing farmers' income. VAA is to transform the primary agricultural commodities from their original form to a more valuable one. It is not only increasing values of the agricultural products, but also reducing deterioration risks, diversifying agricultural commodities and providing food security as well.

Table 1: Value added agriculture

\begin{tabular}{|c|c|c|}
\hline PRIMARY PRODUCTS & SEMI-PRODUCT & FINISHED GOODS \\
\hline Cotton & Cotton lint & Clothes \\
\hline Wheat & Flour & Bakery products \\
\hline Skin & Leather & Shoes \\
\hline
\end{tabular}

By passing different processes and activities (mainly labor), primary agricultural commodities convert to semiproducts or finished products. Each step of the process should add value to the product. The final step focuses on the product's uniqueness (Table 1). A new product has to fulfil needs of consumers and the producer should offer the new product in the market for reasonable price (Horska and Ubreziova, 2003).

Copyright (C) 2017 The Authors. Published by Aleksandras Stulginskis University. This is an open-access article distributed under the terms of the Creative Commons Attribution License (CC-BY 4.0), which permits unrestricted use, distribution, and reproduction in any medium, provided the original author and source are credited. 
Value is usually created by focusing on the benefits associated with the agribusiness product or service that arise from quality, functionality, form, place, time and the ease of possession. A product should have one or more of these qualities to generate additional value (Anderson and Hanselka, 2009). Most of the consumers are willing to pay more for the products, which are already processed and ready to consume than buying raw agricultural products and then spending time with their preparation.

High intellectual and research potential of Uzbekistan can accelerate VAA practice within the country. For this reason, there is need to develop partnership among higher education, research institutes and private sector enjoying updated information and communication technology. The successful partnership produces synergy and create new approaches to the marketing mix of high value-added products in order to meet the needs of today consumers. Moreover, the integration of science with industry can make a significant contribution in the innovative development of the country.

\section{RESEARCH METHODS}

To highlight the economic importance of VAA, there is analysed the agriculture sector in GDP and the production dynamics of the primary agricultural commodities during 2005-2014, as well as the share of cotton, fruits, vegetables and leather in export in 2005 and 2014.

From 2005 to 2009 the share of agriculture sector in GDP is decreasing by 8,5\%, starting 2010 up to 2014 there is insignificant changes ranging 19,2-18,2\%. The industry has increased by 10,5\% in 2014 comparing with 2005. The leading sector is the service and it accounts for $47,5 \%$ in 2014 . This is positive trend, as in most of the developed countries the share of service is the highest and agriculture is the lowest (Figure 1).

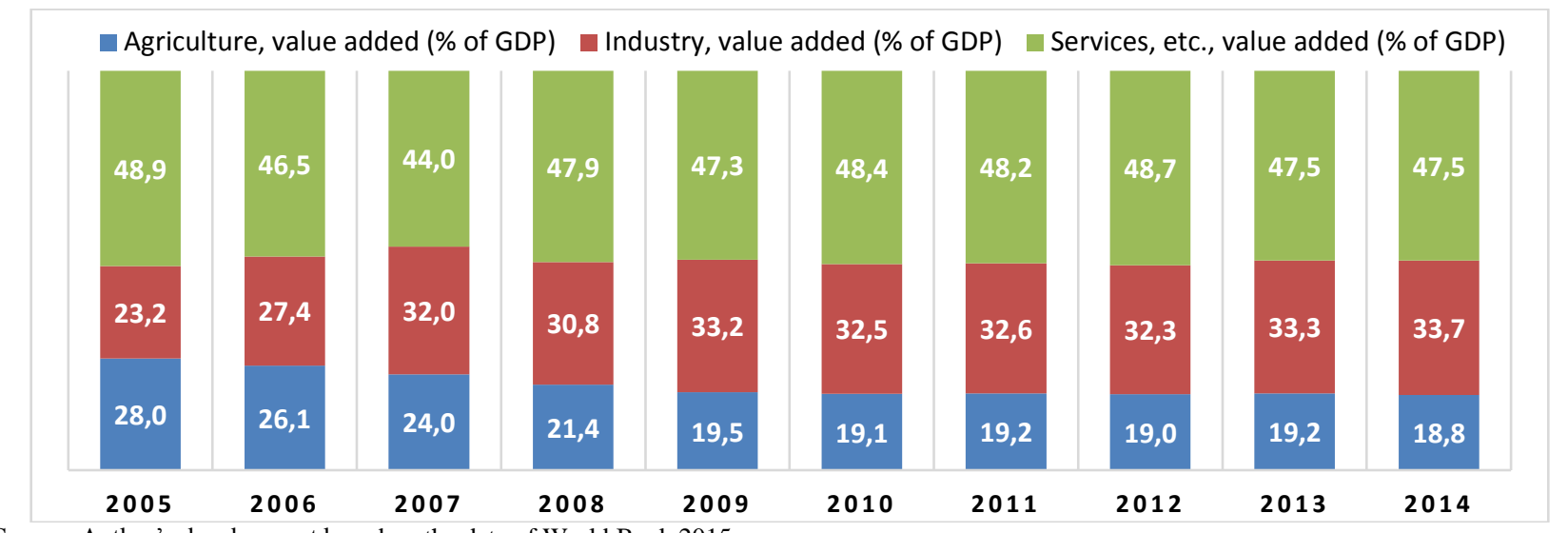

Source: Author's development based on the data of World Bank 2015

Figure 1: Share of sectors in GDP of Uzbekistan

In spite of declining the share of the agriculture in GDP, the volume of the main agricultural products has increased during 2005-2014 period except cotton. If it was 3728,4 thousand tonne in 2005 and it equalled to 3400,3 thousand tonne in 2014. The other agricultural products have grown during these periods. The result connects with reducing the cotton fields and replace them with planting other agricultural products in order to diversify agricultural commodities at the same time to provide food safety (Figure2).

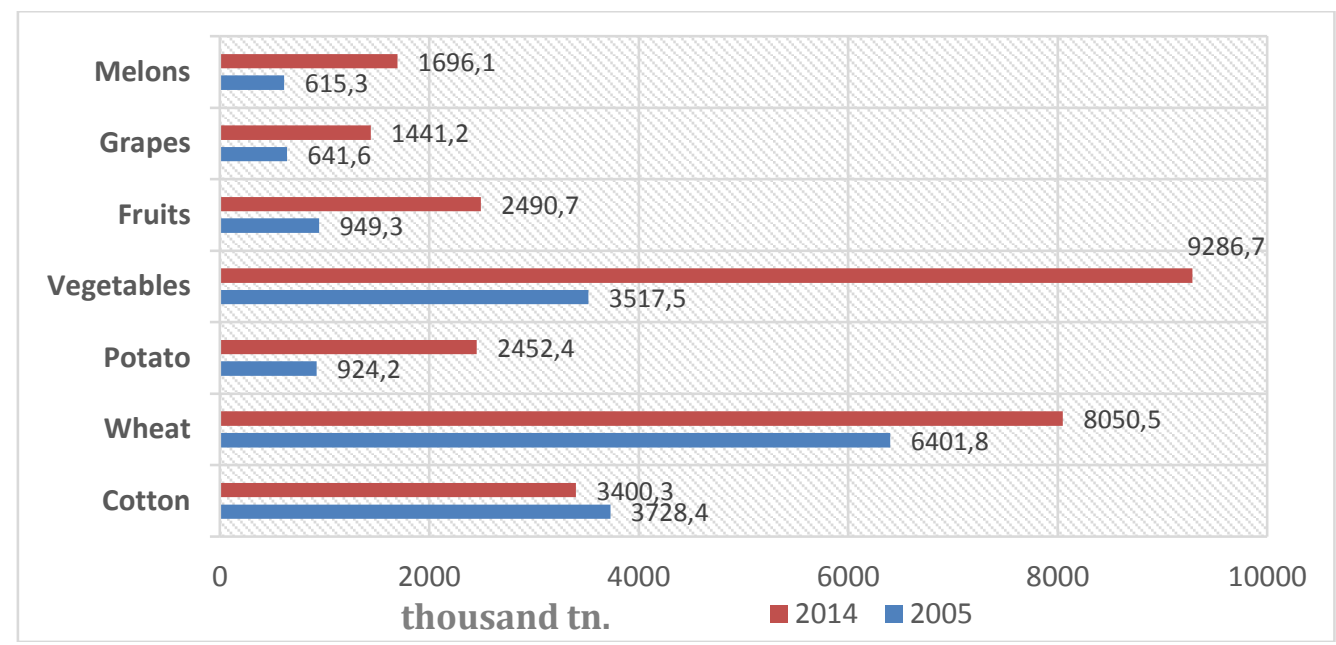

Source: Author's development based on the data of State Committee of the Republic of Uzbekistan on Statistics, 2015

Figure 2: The production dynamics of the primary agricultural commodities 
The falling volume of cotton and transforming it to semi and finished products impact on its share in export. In 2005 the share in value in country's cluster was $31,7 \%$ and it has reduced by 2014 and accounted for $13,73 \%$. The share of fruits and vegetables have insignificantly changed: 9,1\% in 2005 and 8,52\% in 2014 (Table2). Such as tendency should be continued in the republic. Instead of primary agricultural commodities, there is need to export products desired by customers and acquire more benefits in term of the cost. There is also future prospects for decreasing more the share of raw cotton, fruits and vegetables in the export by converting them to semi (cotton lint, fabric etc.) or finished products (clothes), processed food (jam, juice etc.). Annual production potential of fruits and vegetables equals to $10 \mathrm{mln}$. tonne (NFIEZ, 2009).

Table 2: Share of primary agricultural commodities in 2005 and 2014 exports in Uzbekistan

\begin{tabular}{|c|l|c|c|}
\hline № & \multicolumn{1}{|c|}{ Primary agricultural commodities } & $\begin{array}{c}\text { Share in country's } \\
\text { exports, \% in 2005 }\end{array}$ & $\begin{array}{c}\text { Share in country's } \\
\text { exports, \% in 2014 }\end{array}$ \\
\hline 1. & Cotton & 31,07 & 13,73 \\
\hline 2. & Fruits and vegetables & 9,1 & 8,52 \\
\hline 3. & Raw hides and skins and leather & 0,04 & 0,27 \\
\hline
\end{tabular}

Source: Author's development based on the data of Trade Map, www.trademap.org

As for raw hides and skins and leather, their share in exports was 0,04\% and 0,27\% respectively in 2005 and 2014. However, there is big potential to process these products locally and prepare finished products such as shoes and leather coats. Total domestic demand for finished fabrics is $900 \mathrm{mln} . s q . \mathrm{m}$., footwear - $170 \mathrm{mln}$. pairs, and garments - $275 \mathrm{mln}$. units (NFIEZ, 2009). Moreover, practicing VAA in the country, there will be created more food processing enterprises or companies and thus provided with new working places.

Annual growth of the fruit production excluding grapes is $6 \%$ in Central Asia, with Uzbekistan racing $7.2 \%$ and Turkmenistan at 6,1\%. Uzbekistan's output represents 70\% of Central Asia's entire fruit (excluding grapes) production (FAO Statistical Yearbook, 2014). However, according to estimates of national experts from the total annual grown fruits and vegetables in Uzbekistan of about $25-30 \%$ (more than 1 million tonne annually) is lost to waste and does not reach the customer. The long chain of intermediaries and dealers to the end user, reducing profit margins of farmers and dehkan farms, and in general, their cost-effectiveness (Malikov et al., 2016).

By classification FAO, in the case of pome fruits (not elsewhere specified) the other pome fruit is not separately identified; in some countries apples, pears and quinces are reported under this general category. Moreover, the category stone fruits (not elsewhere specified) covers also other stone fruit not separately identified; in some countries, apricots, cherries, peaches, nectarines and plums are reported under this general category.

Table 3: Uzbekistan by the following food and agricultural commodities in the top 10 world rankings in 2013

\begin{tabular}{|c|l|l|l|l|}
\hline $\begin{array}{c}\text { World } \\
\text { Ranking }\end{array}$ & Country & \multicolumn{1}{|c|}{ Commodity } & $\begin{array}{c}\text { Quantity } \\
\text { (tonnes) }\end{array}$ & \multicolumn{1}{|c|}{ Processed products } \\
\hline 1 & Uzbekistan & $\begin{array}{l}\text { Fruits, pome } \\
\text { (not elsewhere specified) }\end{array}$ & 120,000 & $\begin{array}{l}\text { Jam, juice, alcohol, fruit chips, baby food, vinegar, fruit } \\
\text { tea, compote, dried fruits, canned fruits }\end{array}$ \\
\hline 2 & Uzbekistan & Carrots and turnips & $1,641,882$ & $\begin{array}{l}\text { Juice, baby food, compote, turnip chips, cosmetics, } \\
\text { carrot roundels, pickled turnips }\end{array}$ \\
\hline 3 & Uzbekistan & Apricots & 430,000 & $\begin{array}{l}\text { Jam, juice, alcohol, baby food, compote, dried apricots, } \\
\text { canned apricots, apricot pits and seeds, apricot kernel oil, } \\
\text { apricot seed extracts, cosmetics, medicines }\end{array}$ \\
\hline 4 & Uzbekistan & $\begin{array}{l}\text { Fruit, stone } \\
\text { (not elsewhere specified) }\end{array}$ & 40,000 & $\begin{array}{l}\text { Jam, compote, juice, fruit tea, alcohol, dried fruits, } \\
\text { canned fruits }\end{array}$ \\
\hline 4 & Uzbekistan & Jute & 21,000 & Bags, shoes, fibre \\
\hline 5 & Uzbekistan & Cherries & 100,000 & Jam, juice, compote, canned cherries \\
\hline 7 & Uzbekistan & Persimmons & 50,000 & Baby food, sauce, dried persimmons \\
\hline 7 & Uzbekistan & Watermelon & 203,585 & $\begin{array}{l}\text { Garlic oil, spice, powder, flakes, pickled, vinegar, jelly, } \\
\text { sauce, insecticide }\end{array}$ \\
\hline 8 & Uzbekistan & Garlic & 40,000 & Jam, juice, dried cherries, compote \\
\hline 9 & Uzbekistan & Cherries, sour & 607,397 & Pickled, cosmetics \\
\hline 10 & Uzbekistan & Cucumber and gherkins & Pacher \\
\hline
\end{tabular}

Source: Author's development based on the data of Statistics Division of Food and Agriculture Organization of the United Nation, 2016

Uzbekistan was leading in the world in the production of pome fruits (apples, pears, and quince) in 2013. The total volume was 120,000 tonne. It also takes the second place with producing 1,641,882 tonne of carrots and turnips (Table 3 ). There are future prospects for decreasing more the share of raw cotton, fruits and vegetables in the export by converting them to semi (cotton lint, fabric etc.) or finished products (clothes), processed food (jam, juice etc.).

Uzbekistan has the advantage by trading and attracting investment by virtue of the high price for oil, gas and cotton increased in the world market. There are prospects that China's increasing economic ties with the Commonwealth of Independent States and EU countries and the development of transit routes through Central Asia will improve linkages with outside markets. Uzbekistan should take advantage of China's huge population and orient to this market for exporting 
processed food products. Due to the food ban on Russia by the USA and EU countries, Russian's import for food and agricultural products from Uzbekistan is also increasing.

\section{CONCLUSION}

Value added agriculture plays important economic role in both developing national economy and supporting people with new jobs in rural areas. The economic advantages of VAA are increasing the share of finished goods in export, supplying import-substituting products, improving infrastructure in rural areas, and growing people's income. By practicing VAA, it can be meeting the domestic demands for consumer products.

Furthermore, Uzbekistan has a great opportunity for storing, freezing, processing and packaging of a wide nomenclature of fruits, food production and drinks with the organization of their further exports to the perspective markets. VAA provide more processed food products within the country that have longer food durability than raw agricultural products. In case of difficult periods caused by natural phenomenon, food products with high value added are very important to moderate negative influences. There is need to attract more domestic and foreign investments to rural areas, establish tax incentives and allocate preferential credits for agribusiness. With the extensive practice of VAA, existing agricultural challenges in the country can have positive solutions, the exports of value added agriculture products are increasing while foreign exchange earnings are flowing.

The next key factor of implementing VAA practice is considerable human and intellectual potential in the country. The establishment of close cooperation among knowledge triangle (higher education, research and business) gives positive impulse to improve VAA. Knowledge triangle can be an instrument for increasing the efficiency of agricultural production through the introduction of innovations, training and counselling rural commodity producers, creating legal, technical and marketing reference system. Information technology can be convenient means of communication among knowledge triangle elements. At the stage of the innovative development, there is need to get advantage of the academic mobility of students and teachers in universities for the development and integration of university science with the international community, large corporations, foreign enterprises and international funds. The successful partnership among university education, research institutes and business create the synergy benefits in terms of VAA with new processed food products with higher quality, modern design and packaging.

\section{ACKNOWLEDGEMENTS}

It is very pleasure to express my deep gratitude to my supervisors prof. Elena Horska and Dr. Alim Pulatov as well as the PACAgro (543902-TEMPUS-1-2013-1-SK-TEMPUS-SMGR) project for presenting great an opportunity to participate in the 8th International Scientific Conference "Rural Development 2017: Bioeconomy Challenges".

\section{REFERENCES}

1. Anderson, D.P., Hanselka, D. 2009. Adding value to agricultural products. Texas: FARMER Collection

2. Food and Agricultural Organization. 2017. AQUASTAT. Available at http://www.fao.org/nr/water/aquastat/data/query/results.html (Accessed on 07/04/2017)

3. Horska, E., Ubreziova, I. 2003. Innovation management as a tool of qualitative changes in the food processing industry. Zemedelska Ekonomika-Praha, Vol. 49(8), pp. 361-364.

4. Investing in rural people in Uzbekistan, International Fund for Agricultural Development (IFAD) 2015. Available at https://www.ifad.org/documents/10180/0f3d587a-68ab-4997-9b9e-a3be776428bd (Accessed on 10/04/2017)

5. Malikov, N., Qineti, A., Pulatov, A. 2016. Agriculture and economic development in Uzbekistan. International Scientific Days 2016 in Nitra.

6. Navoi Free Industrial Economic Zone. 2009. Free Industrial Economic Zone in Navoi: New Investment Opportunities for Korean Partners in Uzbekistan. Available at http://fiez.uz/presentation/6-new-investment-opportunities-for-korean-partners-inuzbekistan (Accessed on 15/05/2016)

7. Pirmatov, K., Galova, J., Horska, E., 2017. Value-Added Agriculture for Central Asian Countries. Establishing Food Security and Alternatives to International Trade in Emerging Economies, p.135.

8. State Committee of the Republic of Uzbekistan on Statistics. 2016. Available at http://tafsilot.uz/demografik-holatimizraqamlarda/ (Accessed on 20/05/2017)

9. World Bank. 2015. World Development Indicators Available at http://data.worldbank.org/country/uzbekistan (accessed on 14/04/2016)

10. Yearbook, F.S. 2014. Europe and central Asia food and agriculture. Food and Agriculture Organization of the United Nations. Regional Office for Europe and Central Asia. Budapest. 